\title{
Effect of Sporosarcina Pasteurii on the strength properties of compressed earth specimens
}

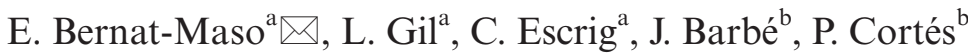

a. Department of Strength of Materials and Engineering Structures. Technical University of Catalonia. (Terrassa, Spain) b. Department of Genetics and Microbiology. Universitat Autònoma de Barcelona, (Cerdanyola del Vallès, Spain) $\triangle$ ernest.bernat@upc.edu

\author{
Received 7 November 2016 \\ Accepted 10 March 2017 \\ Available on line 5 February 2018
}

\begin{abstract}
Microbial biodeposition of calcite induction for improving the performance of rammed earth is a research area that must be analysed in a representative environment. This analysis must consider the compaction force, particle size distribution and curing process as production variables. This paper investigates the effects of adding specific bacteria, Sporosarcina Pasteurii, into compressed earth cubes and the effect of production variables. Uniaxial compressive tests and direct shear tests have been conducted for 80 specimens. The results indicate that calcite precipitation interacts with the drying process of clay/silt resulting in reducing the compressive strength, the apparent cohesion and the friction angle. Finally, bacterial activity, which is more likely in samples cured in a high humidity environment, tends to reduce the dilatancy effect.
\end{abstract}

KEYWORDS: Calcium carbonate; Organic material; Curing; Compressive strength; Characterisation

Citation/Citar como: Bernat-Masó, E.; Gil, L.; Escrig, C.; Barbé, J.; Cortés, P. (2018) Effect of sporosarcina Pasteurii on the strength properties of compressed earth specimens. Mater. Construcc. 68 [329], e143 https://doi.org/10.3989/ mc.2018.12316

RESUMEN: Efecto de la Sporosarcina Pasteurii en las propiedades resistentes de especímenes de tierra comprimida. Inducir la biodeposición microbiana de calcita para mejorar las prestaciones de la tapia es una línea de investigación que necesita ser analizada en condiciones representativas y teniendo en cuenta variables de producción como la fuerza de compactación, la granulometría o el curado a diferentes humedades. Se estudia el efecto de añadir Sporosarcina Pasteurii en cubos de tierra comprimida y la influencia de estas variables de producción. Se han realizado ensayos de compresión simple y corte directo sobre 80 especímenes producidos con dos niveles de compactación y dos granulometrías. Los resultados indican que la precipitación de calcita interactúa con el proceso de secado de los limos/arcillas dando como resultado una reducción de la resistencia a compresión, de la cohesión aparente y del ángulo de fricción. Finalmente, la actividad bacteriana, más probable en las muestras curadas en un entorno de alta humedad, tiende a reducir el efecto de la dilatancia.

PALABRAS CLAVE: Carbonato cálcico; Material orgánico; Curado; Resistencia a la Compresión; Caracterización

ORCID ID: E. Bernat-Masó (http://orcid.org/0000-0002-7080-0957); L. Gil (http://orcid.org/0000-0002-2007-4846); C. Escrig (http://orcid.org/0000-0002-2412-007X ); J. Barbé (http://orcid.org/0000-0003-4408-013X ); P. Cortés (http://orcid.org/0000-0002-5924-0653);

Copyright: (C) 2018 CSIC. This is an open-access article distributed under the terms of the Creative Commons Attribution 4.0 International (CC BY 4.0) License. 


\section{INTRODUCTION}

Earthen construction has been used for thousands of years around the world due to its high availability of material, simple building procedure and the properties of the resulting buildings (1). Although site-adapted particular techniques were historically developed (see Miccoli et al. (2)), this technology has been replaced by concrete and steel structures in the last century in most of the countries. However, rising concern regarding environmental sustainability has brought renewed interest to earthen construction.

The historical evolution of earthen construction has presented the possibility of mixing earth with industrially produced chemical binders with the aim of increasing the resulting mixture's mechanical properties in order to meet current structural requirements. However, these procedures may not conform to applicable sustainability objectives. Thus, new environmentally friendly additives are necessary. To this end, using microbial bio-deposition of calcite is gaining increased attention. According to DeJong et al. (3) and Stocks-Fischer et al. (4), the first applications of microbial biodeposition, which occurred approximately 30 years ago, were aimed at sealing oil reservoirs. Ever since, researchers have studied the variables that influence the biological and chemical reactions that control the microbial bio-deposition of calcite. In brief, some bacterial activity is capable of modifying the $\mathrm{pH}$ level of the cell, which allows the combination of surrounding ions to precipitate calcite. In fact, the surface of the bacterial cell is a nucleation site where the heterogeneous nucleation occurs, forming a self-organised structure of $\mathrm{CaCO}_{3}$. This means that the surface of the bacteria is the most likely place where the formation of $\mathrm{CaCO}_{3}$ will start. A detailed explanation of these biological and chemical processes for the Bacillus Pasteurii bacterium, the most studied bacterium, can be found in works by DeJong et al. (3), Stocks-Fischer et al. (4) and Ivanov et al. (5). The first team, (3), studied the main variables that influence the bio-deposition of calcite: $\mathrm{pH}$, the concentration of oxygen, the amount of bacterial cells and the concentration of ions in the media. The second investigation, (4), focused on controlling the activity of Bacillus Pasteurii and its effectiveness in depositing calcite by measuring $\mathrm{NH}_{3}$ levels. They set an optimum $\mathrm{pH}$ level between 8.3 and 9. Finally, Ivanov et al. (5) proposed setting the $\mathrm{pH}$ level at over 8.5 and concluded that the concentration of calcium ion must be $0.75 \mathrm{M}$ or higher to allow the precipitation of calcite.

Although the bacterial bio-deposition of calcite is a natural process that occurs in soils, most research on this topic has been conducted on mortar and concrete elements. De Muynck et al. (6) studied methods to reduce the permeability of mortar surfaces by implementing a superficial treatment with bacteria. In this research, the calcium source was determined to be a significant variable. Ramachandran et al. (7) concluded that adding an excessive amount of Bacillus Pasteurii in mortar cubes might reduce their compressive strength as voids appear in the position occupied by bacteria when they die. In this line, they proposed an optimum cell concentration of $5 \times 10^{7}$ cell $/ \mathrm{cm}^{3}$. Similarly, Chunxiang et al. (8) studied methods to optimise the bio-deposition of calcite and concluded that slowing the reaction by adding the calcium ions and the substrate for bacteria (urea) at different times led to a more compact and bonded calcite that reduced the permeability of the cement mortar samples. Regarding the calcium source in concrete elements, Jonkers et al. (9) concluded that calcium lactate was the best option because it does not produce ammonia, contain chlorides or reduce the compressive strength of the mortar. Nevertheless, the effect of adding bacteria on the mechanical properties of mortars has been insufficiently investigated. Sierra-Beltran et al. (10) focused on analysing the effect of adding bacteria on the density, the compressive strength, the tensile strength and the shrinkage of repairing mortar.

Moreover, it should be noted that several researchers proposed encapsulating bacteria and/or its substrate to produce auto-healing concrete. Significant conclusions arise from these studies. Controversially, Bang et al. (11) and Bachmeier et al. (12) suggested that bio-deposited calcite might contribute to an increase in the compressive strength, yet it would not act as a binder, and thus the encapsulation would not have a negative effect. Later, Bang et al. (13) studied the durability and mechanical properties of mortars which included encapsulated bacteria and concluded that the maximum concentration of Bacillus Pasteurii should be $6 \times 10^{8}$ cell $/ \mathrm{cm}^{3}$. Finally, Jonkers (14) and Wang et al. (15) used porous expanded clay particles and melamine, respectively, to encapsulate bacteria, prolonging their activity period and making it possible to mix them in fresh concrete without damaging the cells.

Finally, it should be noted that there is little recent research regarding the cementation of earth materials with bacterial bio-deposition. One of the most significant works is the study by Van Paassen et al. (16), who used a $5 \mathrm{~m}^{3}$ biological reactor to produce enough cells to consolidate the soil under a real-scale foundation, demonstrated the technical feasibility of the system. According to this research, between $60 \mathrm{~kg}$ and $600 \mathrm{~kg}$ of $\mathrm{CaCO}_{3}$ are required to stabilise $1 \mathrm{~m}^{3}$ of soil.

Thus, the literature indicates that it is possible to modify the properties of granular soils by adding bacteria. However, there is no evidence regarding the effect of this adaptation on the strength properties of earthen construction materials, such as rammed earth or compressed earth blocks. In addition, most 
previous research (see (3), (7) or (8)) has been conducted on controlled standardised soils or mortars, and thus performing research on generally available earth materials is necessary. Finally, the majority of references (see (3), (8) or (13)) suggest that the application of treatments that last several days was necessary to activate the bacterial reaction, whereas producing an in situ competitive construction material required a shortened treatment time. In fact, it has been studied and proposed to mix the bacteria and its substrate with the soil to produce a modified earthen material, with no additional treatment nor complex curing process. Thus, in order to cover the previously mentioned gaps of knowledge, an experimental programme has been developed to analyse the effect of adding bacteria, Sporosarcina Pasteurii, to earth compressed cubes with regard to their compressive strength, apparent cohesion and internal friction angle, using two non-standardised soils, two different compression levels and two curing strategies to produce the cubes.

\section{MATERIALS AND METHODS}

The experimental programme consisted of manufacturing and testing of 80 cubic specimens produced with two different levels of compression (20 specimens compressed at $4 \mathrm{kN}$ and 60 specimens compressed at $2 \mathrm{kN}$ ) and two distributions of particle sizes (40 specimens for each case). In addition, 40 specimens included bacteria while the other 40 did not include bacteria. Finally, 20 of these specimens were cured in a high humidity environment $(\mathrm{RH}>$ $95 \%$ ) for 14 days. Specimens were tested under direct shear tests ( 8 for each type) or uniaxial compressive test ( 2 for each type). See Table 1.

\subsection{Earth}

To date, studies used a single particle type: plain sand. This approach was not realistic and its applicability was limited due to the composition and particle size of real soils being rather heterogeneous. Thus, this research used non-standardised earthen components to test the feasibility of the technology. Therefore, the particle size distribution was wider than that used in previous studies.

The earthen mixture was composed of clay, silt and sand with two different ratios. For the first mixture (labelled "A"), the proportion of each component was $40 \%$ clay and silt, $45 \%$ sand with particles up to $2 \mathrm{~mm}$ and $15 \%$ sand with particles up to $5 \mathrm{~mm}$. For the second mixture (labelled "B"), the proportion of each component was $10 \%$ clay and silt, $65 \%$ sand with particles up to $2 \mathrm{~mm}$ and $25 \%$ sand with particles up to $5 \mathrm{~mm}$. The particle size distribution of these two mixtures is presented in Figure 1. Mixture A was used in previous research (17).

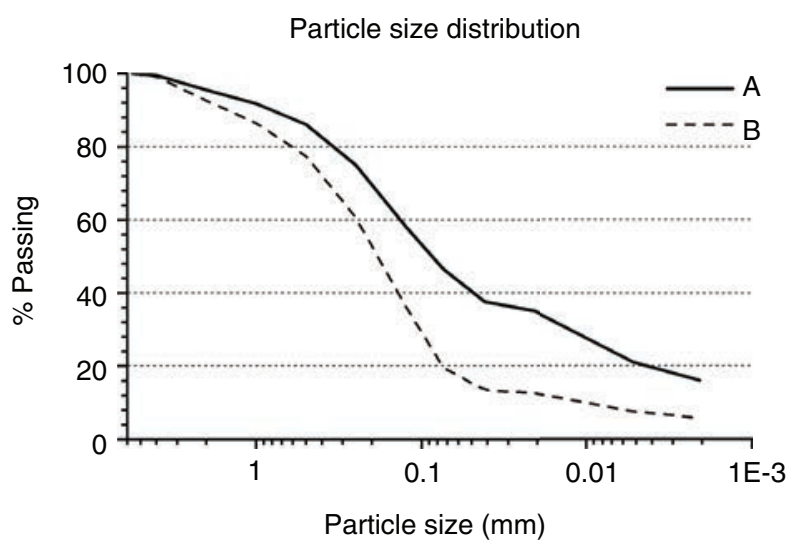

Figure 1. Nomogram of the particle size distributions ( $A$ and $B$ ) of the earth mixtures used to produce the specimens (see Table 1).

Finally, the most significant components of the used clay were $40-45 \% \mathrm{SiO}_{2}, 10-13 \% \mathrm{Al}_{2} \mathrm{O}_{3}$ and $3-5 \%$ $\mathrm{Fe}_{2} \mathrm{O}_{3}$. The silicate modulus was 2.53.

\subsection{Sporosarcina Pasteurii}

Sporosarcina Pasteurii (S. Pasteurii) was selected as the most suitable bacteria to consolidate soils according to previous research (3).

Preparation of bacterial suspension for consolidation was performed as follows. S. Pasteurii DSM 33 (Leibniz Institute DSMZ-German Collection of Microorganisms and Cell Cultures) was grown in 10 $\mathrm{ml}$ of Bang medium broth (11) for $18 \mathrm{~h}$ at $30^{\circ} \mathrm{C}$. The next day, new cultures were prepared (dilution 1:100) in Bang broth and were incubated overnight at $30^{\circ} \mathrm{C}$ until arriving at an optical density at $600 \mathrm{~nm}\left(\mathrm{OD}_{600}\right)$ of 1. Optical density is a measurement of the absorbance of light at a fixed wave length used to control the concentration of cells in a suspension. Cells were harvested by centrifugation at $8,000 \mathrm{rpm}$ for $10 \mathrm{~min}$. Pellets were suspended in a final volume of $960 \mathrm{ml}$ of Bang medium supplemented with $2 \%$ of $\mathrm{CaCl}_{2}(140$ $\mathrm{g} / \mathrm{l})$ and adjusting the optical density until reaching an $\mathrm{OD}_{600}$ value of 1.4-1.6. Viable counts of $S$. Pasteurii were determined by plating the dilution on Bang medium agar (1.5\%). The concentration of the final liquid suspensions was adjusted to obtain values of approximately 7 to $9 \times 10^{8} \mathrm{cfu} / \mathrm{ml}$.

\subsection{Specimens production and curing}

The procedure for manufacturing the specimens consisted of the following steps: A) manually mix earthen components to obtain a uniform distribution of the particles. B) Add the liquid component, which was comprised of drinking water from the local supply for the control cases (40 specimens) and a suspension containing the bacteria, the calcium source and the substrate (see section 2.2) for the remainder of the specimens (40 specimens). In both 
cases, the total amount of added liquid (1 1) was the necessary to reach a final water content of $12.6 \%$. C) Manually mix the solid and liquid phases to obtain a uniform wet earthen material. D) Fill the cubic $100 \mathrm{~mm}$ x100 mm x $100 \mathrm{~mm}$ mould. Manually apply a low pressure to ensure a complete filling of the mould. E) Statically compact the earthen material with an electromechanical press, which transmitts a controlled force though a steel plate placed on the specimen. In this study, this load was applied at a rate of $25 \mathrm{~N} / \mathrm{s}$ or $50 \mathrm{~N} / \mathrm{s}$ for the specimens produced with a compressive load of $2 \mathrm{kN}$ or $4 \mathrm{kN}$, respectively (see Table 1). F) Remove the specimen from the mould and cure it for a minimum of 14 days under indoor ambient conditions (temperature $25 \pm 2^{\circ} \mathrm{C}, \mathrm{RH}=$ $65 \pm 10 \%$ ). In addition, 20 specimens were cured at $\mathrm{T}=25 \pm 1^{\circ} \mathrm{C}$ and $\mathrm{RH}$ over $95 \%$ for 14 days. $\mathrm{G}$ ) Finally, dry the cubes under indoor ambient conditions $\left(\mathrm{T}=25 \pm 2^{\circ} \mathrm{C}, \mathrm{RH}=65 \pm 10 \%\right.$ ) for 14 additional days. Figure 2 shows specimens 2CA and 4CA. The fabrication variables and the corresponding labelling for each specimen are presented in Table 1 .

Cubic specimens of $100 \mathrm{~mm}$ edges were chosen for this study in order to standardise the shape of the specimens. Standards recommend cylindrical specimens with a height to diameter ratio of approximately 2 for compressive strength tests and narrower specimens with a height to diameter ratio of less than 0.4 for direct shear tests. However, these shapes and their typical dimensions $(50 \mathrm{~mm}$ diameter for compressive strength specimens) were designed for soil-lime materials, whereas the proposed methodology was implemented for testing rammed earth with typical particle dimensions of up to $30 \mathrm{~mm}$ in future research. Thus, the size of the specimen was defined as 3 times the maximum particle size expected in common rammed earth. In this context, and considering that $80 \%$ of the specimens were to be tested in direct shear, common square cubes of $100 \mathrm{~mm}$ (typically used for determining the compressive strength of concrete) were selected as this shape is closer to the requirements of the direct shear test typically used for compression tests.

Using water from the local system introduced a small amount of calcium in the form of $\mathrm{CaCO}_{3}$ to the control cases. However, this additional calcium was not considered because the maximum allowable

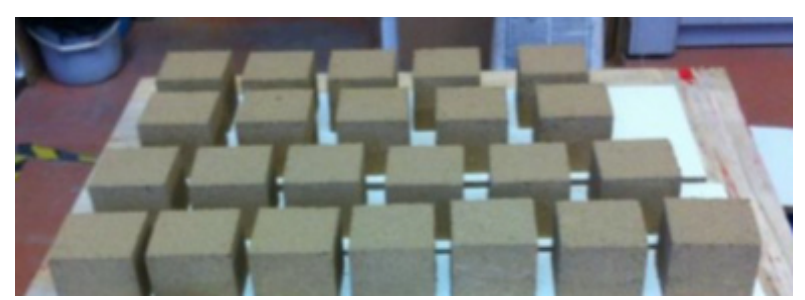

Figure 2. Specimens 2CA and 4CA, and three additional specimens with no bacteria to control the evolution of the moisture content. amount of $\mathrm{CaCO}_{3}$ in the water supply system is $500 \mathrm{mg} / 1$ (according to OMS limitations), which is negligible in light of the $140 \mathrm{~g} / 1$ of $\mathrm{CaCl}_{2}$ used as the calcium source. In addition, the $\mathrm{CaCO}_{3}$ supplied by the water did not influence the bonding between particles because this compound was already formed when water was added to the mixture. In contrast, microbially deposited $\mathrm{CaCO}_{3}$ was formed between the particles of the specimens and may have had a bonding effect between particles.

The apparent density of each cube was determined at the moment of manufacturing the specimens. Dry density and moisture content were determined at the moment of testing. All measurements are summarised in Table 2 .

Water content, curing time and drying time were considered to be the crucial variables. Thus, preliminary characterisation tests were performed to set these variables before producing the definitive specimens. A drop ball test, used in previous research (17), indicated that a water content level of $12.6 \%$ for the earthen material was suitable for the production of compacted specimens. The evolution of the moisture content along time was monitored in a preliminary campaign. Some cubic samples were weighed at different ages before and after drying in an oven for $24 \mathrm{~h}$ at $105^{\circ} \mathrm{C}$. Tracking of these samples showed that moisture levels became stable (changes of less than $2 \%$ ) after two weeks of drying. Hence, this threshold time was set as the drying time. The moisture content at manufacturing and the moisture content at testing were obtained by drying additional specimens, which were produced together with the tested ones.

Although specimens contained a significant amount of clay-size fraction, the characteristic cracking associated with the shrinkage phenomena during the drying process was not observed. It should be noted that specimens with Sporosarcina Pasteurii generated a strong smell during the drying process. For samples not cured in a high humidity environment, the maximum peak of this phenomenon occurred 7 days after the manufacturing date, when the moisture content of the specimens was under $3 \%$. For specimens cured in a high humidity environment, this peak occurred 7 days after the beginning of the drying process under indoor conditions.

\subsection{Testing setup and procedure}

To compare the mechanical properties of cubes with and without added bacteria, two types of test were defined: uniaxial compression testing and direct shear testing. These tests were based on standards ASTM D5102-04 (18) and ASTM D6528-00 (19), respectively. However, the methodology was adapted to use larger cubic specimens. This shape was chosen (see section 2.3) to standardise the shape and dimensions of the specimens in the research. 
TABLE 1. Samples definition and the corresponding testing procedure

\begin{tabular}{|c|c|c|c|c|c|c|c|c|c|c|c|}
\hline 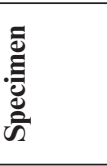 & 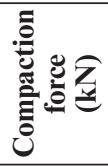 & 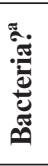 & 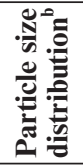 & 照 & 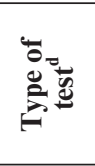 & 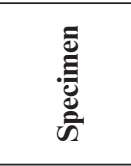 & 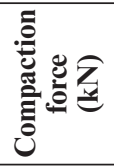 & صृّ & 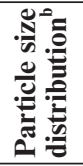 & U & 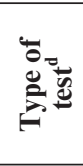 \\
\hline $2 \mathrm{CA} 1$ & 2 & $\mathrm{~N}$ & A & $\mathrm{N}$ & $\mathrm{C}$ & 4CA1 & 4 & $\mathrm{~N}$ & A & $\mathrm{N}$ & $\mathrm{C}$ \\
\hline 2CA2 & 2 & $\mathrm{~N}$ & A & $\mathrm{N}$ & $\mathrm{C}$ & 4CA2 & 4 & $\mathrm{~N}$ & A & $\mathrm{N}$ & $\mathrm{C}$ \\
\hline $2 \mathrm{CA} 3$ & 2 & $\mathrm{~N}$ & A & $\mathrm{N}$ & $\mathrm{CS} 3$ & $4 \mathrm{CA} 3$ & 4 & $\mathrm{~N}$ & A & $\mathrm{N}$ & $\mathrm{CS} 3$ \\
\hline 2CA4 & 2 & $\mathrm{~N}$ & A & $\mathrm{N}$ & $\mathrm{CS} 3$ & 4CA4 & 4 & $\mathrm{~N}$ & A & $\mathrm{N}$ & $\mathrm{CS} 3$ \\
\hline $2 \mathrm{CA} 5$ & 2 & $\mathrm{~N}$ & A & $\mathrm{N}$ & CS6 & $4 \mathrm{CA} 5$ & 4 & $\mathrm{~N}$ & A & $\mathrm{N}$ & CS6 \\
\hline $2 \mathrm{CA} 6$ & 2 & $\mathrm{~N}$ & A & $\mathrm{N}$ & CS6 & 4CA6 & 4 & $\mathrm{~N}$ & A & $\mathrm{N}$ & CS6 \\
\hline $2 \mathrm{CA} 7$ & 2 & $\mathrm{~N}$ & A & $\mathrm{N}$ & CS9 & $4 \mathrm{CA} 7$ & 4 & $\mathrm{~N}$ & A & $\mathrm{N}$ & CS9 \\
\hline $2 \mathrm{CA} 8$ & 2 & $\mathrm{~N}$ & A & $\mathrm{N}$ & CS9 & $4 \mathrm{CA} 8$ & 4 & $\mathrm{~N}$ & A & $\mathrm{N}$ & CS9 \\
\hline $2 \mathrm{CA} 9$ & 2 & $\mathrm{~N}$ & A & $\mathrm{N}$ & $\mathrm{CS} 12$ & 4CA9 & 4 & $\mathrm{~N}$ & A & $\mathrm{N}$ & $\mathrm{CS} 12$ \\
\hline 2CA10 & 2 & $\mathrm{~N}$ & A & $\mathrm{N}$ & $\mathrm{CS} 12$ & 4CA10 & 4 & $\mathrm{~N}$ & A & $\mathrm{N}$ & $\mathrm{CS} 12$ \\
\hline $2 \mathrm{CB} 1$ & 2 & $\mathrm{~N}$ & B & $\mathrm{N}$ & $\mathrm{C}$ & 2HCB1 & 2 & $\mathrm{~N}$ & B & $\mathrm{Y}$ & $\mathrm{C}$ \\
\hline 2CB2 & 2 & $\mathrm{~N}$ & B & $\mathrm{N}$ & $\mathrm{C}$ & 2HCB2 & 2 & $\mathrm{~N}$ & B & $\mathrm{Y}$ & $\mathrm{C}$ \\
\hline 2CB3 & 2 & $\mathrm{~N}$ & B & $\mathrm{N}$ & $\mathrm{CS} 3$ & 2HCB3 & 2 & $\mathrm{~N}$ & B & $\mathrm{Y}$ & $\mathrm{CS} 3$ \\
\hline $2 \mathrm{CB} 4$ & 2 & $\mathrm{~N}$ & B & $\mathrm{N}$ & $\mathrm{CS} 3$ & 2HCB4 & 2 & $\mathrm{~N}$ & B & Y & $\mathrm{CS} 3$ \\
\hline $2 \mathrm{CB} 5$ & 2 & $\mathrm{~N}$ & B & $\mathrm{N}$ & CS6 & 2HCB5 & 2 & $\mathrm{~N}$ & B & $\mathrm{Y}$ & CS6 \\
\hline 2CB6 & 2 & $\mathrm{~N}$ & B & $\mathrm{N}$ & CS6 & 2HCB6 & 2 & $\mathrm{~N}$ & B & $\mathrm{Y}$ & CS6 \\
\hline $2 \mathrm{CB} 7$ & 2 & $\mathrm{~N}$ & B & $\mathrm{N}$ & CS9 & 2HCB7 & 2 & $\mathrm{~N}$ & B & $\mathrm{Y}$ & CS9 \\
\hline $2 \mathrm{CB} 8$ & 2 & $\mathrm{~N}$ & B & $\mathrm{N}$ & CS9 & 2НCB8 & 2 & $\mathrm{~N}$ & B & Y & CS9 \\
\hline $2 \mathrm{CB} 9$ & 2 & $\mathrm{~N}$ & B & $\mathrm{N}$ & CS12 & 2HCB9 & 2 & $\mathrm{~N}$ & B & Y & $\mathrm{CS} 12$ \\
\hline $2 \mathrm{CB} 10$ & 2 & $\mathrm{~N}$ & B & $\mathrm{N}$ & CS12 & 2HCB10 & 2 & $\mathrm{~N}$ & B & $\mathrm{Y}$ & $\mathrm{CS} 12$ \\
\hline 2BA1 & 2 & $\mathrm{Y}$ & A & $\mathrm{N}$ & $\mathrm{C}$ & 4BA1 & 4 & $\mathrm{Y}$ & A & $\mathrm{N}$ & $\mathrm{C}$ \\
\hline 2BA2 & 2 & $\mathrm{Y}$ & A & $\mathrm{N}$ & $\mathrm{C}$ & 4BA1 & 4 & $\mathrm{Y}$ & A & $\mathrm{N}$ & $\mathrm{C}$ \\
\hline 2BA3 & 2 & $\mathrm{Y}$ & A & $\mathrm{N}$ & $\mathrm{CS} 3$ & 4BA1 & 4 & $\mathrm{Y}$ & A & $\mathrm{N}$ & $\mathrm{CS} 3$ \\
\hline 2BA4 & 2 & $\mathrm{Y}$ & A & $\mathrm{N}$ & $\mathrm{CS} 3$ & 4BA1 & 4 & $\mathrm{Y}$ & A & $\mathrm{N}$ & $\mathrm{CS} 3$ \\
\hline $2 \mathrm{BA} 5$ & 2 & $\mathrm{Y}$ & A & $\mathrm{N}$ & CS6 & 4BA1 & 4 & $\mathrm{Y}$ & A & $\mathrm{N}$ & CS6 \\
\hline 2BA6 & 2 & $\mathrm{Y}$ & A & $\mathrm{N}$ & CS6 & $4 \mathrm{BA} 1$ & 4 & $\mathrm{Y}$ & A & $\mathrm{N}$ & CS6 \\
\hline $2 \mathrm{BA} 7$ & 2 & $\mathrm{Y}$ & A & $\mathrm{N}$ & CS9 & 4BA1 & 4 & $\mathrm{Y}$ & A & $\mathrm{N}$ & CS9 \\
\hline $2 \mathrm{BA} 8$ & 2 & $\mathrm{Y}$ & A & $\mathrm{N}$ & CS9 & 4BA1 & 4 & $\mathrm{Y}$ & A & $\mathrm{N}$ & CS9 \\
\hline 2BA9 & 2 & $\mathrm{Y}$ & A & $\mathrm{N}$ & $\mathrm{CS} 12$ & 4BA1 & 4 & $\mathrm{Y}$ & A & $\mathrm{N}$ & $\mathrm{CS} 12$ \\
\hline 2BA10 & 2 & $\mathrm{Y}$ & A & $\mathrm{N}$ & CS12 & 4BA10 & 4 & $\mathrm{Y}$ & A & $\mathrm{N}$ & $\mathrm{CS} 12$ \\
\hline 2BB1 & 2 & $\mathrm{Y}$ & B & $\mathrm{N}$ & $\mathrm{C}$ & 2НBB1 & 2 & $\mathrm{Y}$ & B & Y & $\mathrm{C}$ \\
\hline 2BB2 & 2 & $\mathrm{Y}$ & B & $\mathrm{N}$ & $\mathrm{C}$ & 2HBB2 & 2 & $\mathrm{Y}$ & B & $\mathrm{Y}$ & $\mathrm{C}$ \\
\hline 2BB3 & 2 & $\mathrm{Y}$ & B & $\mathrm{N}$ & $\mathrm{CS} 3$ & 2HBB3 & 2 & $\mathrm{Y}$ & B & $\mathrm{Y}$ & $\mathrm{CS} 3$ \\
\hline 2BB4 & 2 & $\mathrm{Y}$ & B & $\mathrm{N}$ & $\mathrm{CS} 3$ & 2НBB4 & 2 & $\mathrm{Y}$ & B & Y & $\mathrm{CS} 3$ \\
\hline 2BB5 & 2 & $\mathrm{Y}$ & B & $\mathrm{N}$ & CS6 & 2HBB5 & 2 & $\mathrm{Y}$ & B & $\mathrm{Y}$ & CS6 \\
\hline 2BB6 & 2 & $\mathrm{Y}$ & B & $\mathrm{N}$ & CS6 & 2НBB6 & 2 & $\mathrm{Y}$ & B & $\mathrm{Y}$ & CS6 \\
\hline 2BB7 & 2 & $\mathrm{Y}$ & B & $\mathrm{N}$ & CS9 & 2HBB7 & 2 & $\mathrm{Y}$ & B & Y & CS9 \\
\hline 2BB8 & 2 & $\mathrm{Y}$ & B & $\mathrm{N}$ & CS9 & 2НBB8 & 2 & $\mathrm{Y}$ & B & Y & CS9 \\
\hline 2BB9 & 2 & $\mathrm{Y}$ & B & $\mathrm{N}$ & $\mathrm{CS} 12$ & 2НBB9 & 2 & $\mathrm{Y}$ & B & $\mathrm{Y}$ & $\mathrm{CS} 12$ \\
\hline 2BB10 & 2 & $\mathrm{Y}$ & B & $\mathrm{N}$ & $\mathrm{CS} 12$ & 2НBB10 & 2 & $\mathrm{Y}$ & B & $\mathrm{Y}$ & $\mathrm{CS} 12$ \\
\hline
\end{tabular}

${ }^{a} \mathrm{~N}$ : without bacteria; Y: with bacteria

${ }^{\mathrm{b}}$ A/B: Particle size distribution according with Figure 1.

N : no curing process; Y: cured @ RH >95\% for 14 days

${ }^{\mathrm{d}} \mathrm{C}$ : Uniaxial compression test; CS3: Confined Compression-Shear test at a compression level of 3kN; CS6: Confined CompressionShear test at a compression level of $6 \mathrm{kN}$; Confined Compression-Shear test at a compression level of $9 \mathrm{kN}$; Confined CompressionShear test at a compression level of $12 \mathrm{kN}$. 
TABle 2. Apparent density, dry density and moisture content at testing time

\begin{tabular}{lccc}
\hline Specimen type & Apparent density $\left(\mathbf{g} / \mathbf{c m}^{3}\right)$ & Dry density $\left(\mathbf{g} / \mathbf{c m}^{3}\right)$ & Moisture content when tested $(\%)$ \\
\hline $2 \mathrm{CA}$ & 1.96 & 1.74 & 1.5 \\
$4 \mathrm{CA}$ & 1.98 & 1.76 & 1.9 \\
$2 \mathrm{CB}$ & 1.78 & 1.58 & 3.2 \\
$2 \mathrm{HCB}$ & 1.78 & 1.58 & 1.6 \\
$2 \mathrm{BA}$ & 1.79 & 1.59 & 1.6 \\
$4 \mathrm{BA}$ & 1.92 & 1.71 & 2.0 \\
$2 \mathrm{BB}$ & 1.81 & 1.58 & 2.3 \\
$2 \mathrm{HBB}$ & 1.80 & 1.57 & 2.3 \\
\hline
\end{tabular}

\subsubsection{Uniaxial compression tests}

To perform uniaxial compression tests, each specimen was placed between two square steel plates of $100 \mathrm{~mm}$ edges and $3 \mathrm{~mm}$ thickness. One plate was placed below the specimen and the other was placed above it. A hydraulic actuator was used to apply a constant descending displacement $(2 \mathrm{~mm} / \mathrm{min})$ on the upper steel plate (see Figure 3, a). This loading rate conformed to the standard ASTM D510204 (18). Thus, the compressive force was directly applied through an imposed displacement, which was measured by the internal LVDT sensor of the hydraulic actuator. A load cell integrated in the actuator measured the acting force, which was continuously recorded with an acquisition system. The test concluded when the vertical compressive load decreased. Two repetitions of the uniaxial compression test were conducted for each combination of the production variables for 16 specimens in total. A list of the tested specimens is shown in Table 1 indicated by the label test $\mathrm{C}$.

\subsubsection{Direct shear tests}

An undrained confined direct shear test setup was implemented to obtain the apparent internal friction angle and the apparent cohesion of the tested earthen materials. The confined configuration eases testing materials with little apparent cohesion and represents the behaviour of the bulk material in the core of a rammed earth element in a more realistic approach than an unconfined setup. Undrained conditions are used to represent the effect of variable actions applied for a short time, such as a gust of wind.

The system consisted of a $100 \mathrm{~mm}$ edge cubic shear box. The sample was placed within the shear box. The movement of the top half of the box was restrained, whereas the bottom half could move along one direction perpendicular to the normal stress. This movement was possible because the bottom part of the shear box was supported on a series of rods placed on a plane surface (see Figure $3 \mathrm{~b}$ and $3 \mathrm{c}$ ).
The normal stress was applied using a hydraulic actuator. This normal stress reached $0.3 \mathrm{MPa}$, $0.6 \mathrm{MPa}, 0.9 \mathrm{MPa}$ or $1.2 \mathrm{MPa}$, depending on the test. The load was applied at a rate of $2 \mathrm{kN} / \mathrm{min}$ to assure undrained conditions. Once the intended normal stress was reached, a second hydraulic actuator imposed a horizontal displacement to the bottom part of the shear box at a rate of $2 \mathrm{~mm} / \mathrm{min}$ while the normal stress was maintained constant. This loading rate was set according to the standard ASTM D6528-00 (19). The load cell integrated in this second actuator measured the applied horizontal force during the test. The displacement of both actuators was continuously measured by their internal LVDT sensors. The test concluded when the maximum horizontal load was reached. An acquisition system recorded the synchronised data (force and displacement) of both actuators.

The acquired displacement data was used to analyse the volume change of the cubes, which made it possible to study the compression/dilatancy effects during shearing.

Two repetitions of the direct shear test were conducted for each combination of production variables and normal stress. Thus, a total of 64 specimens were tested using this procedure. The tested specimens are summarised in Table 1, corresponding to the test types referred to as CS3, CS6, CS9 and CS12.

\section{RESULTS}

The moisture content was measured before every test, though it was not controlled during the testing. The tests took less than 15 minutes and were developed under indoor laboratory conditions. Therefore, it is believed that the matric suction did not affect the test results. In fact, the goal was to discover trends and analyse the effect of the different variables from a qualitative point of view.

\subsection{Uniaxial compression tests}

All tested specimens failed with the same pattern, presented in Figure 4, under uniaxial compression force. This failure mode is typical for 


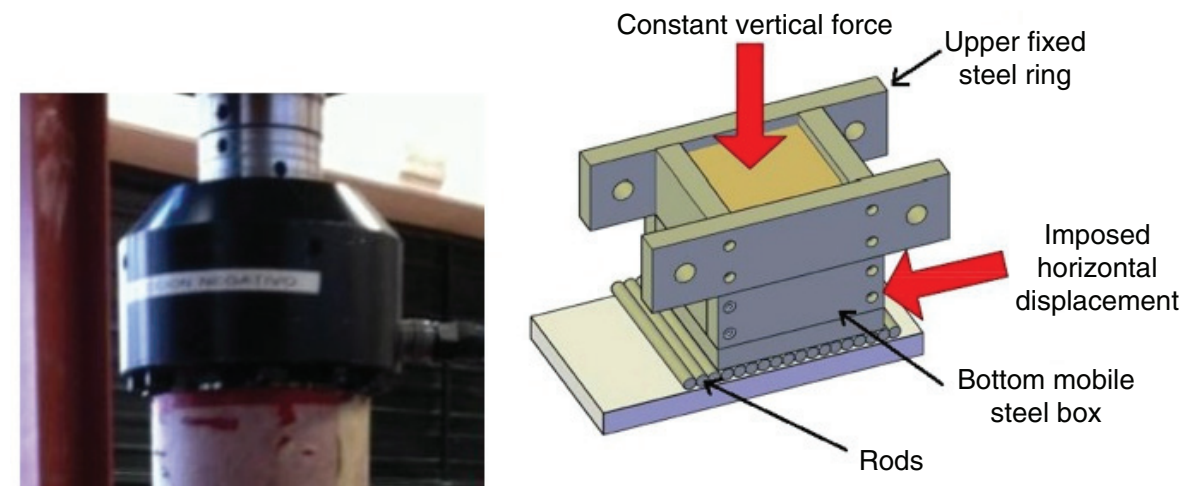

b) Confined Compression-Shear test system

a) Uniaxial Compression Test setup

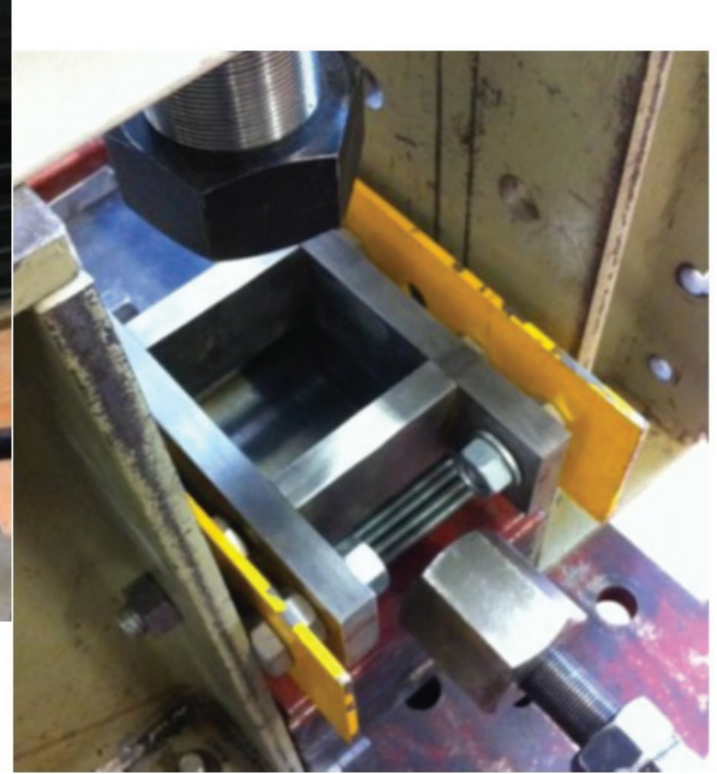

c) Confined Compression-Shear test setup

FIgURE 3. Test setup for uniaxial compression test (a) and direct shear test (b and c).

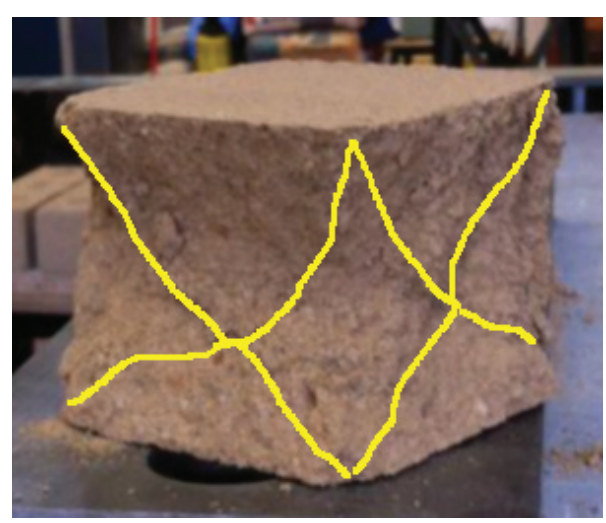

FIGURE 4. Failure pattern of the specimen 4CA2. Cracks marked.

standardised compression tests on cubic samples of brittle materials (see (20)). The material near the four free lateral surfaces failed due to the
Poisson effect and the collapsed specimen took the shape of two opposite pyramids in contact at their vertexes.

The compressive strength for each type of specimen is shown in Figure 5. The values presented in this graph correspond to the average of the two repetitions for each combination of material and production variables. The corresponding coefficient of variation is presented above every mean value. Detailed results are presented in Table 3.

Figure 6 shows a typical force vs. displacement curve obtained from a uniaxial compression test. In the first phase, the specimen is settling, then a linear branch, representing the elastic phase, is observed. Finally, the material softens near the maximum compressive strength. This qualitative response was observed for all tested samples (labelled with test type "C" in Table 1), with and without added bacteria. 


\subsection{Direct shear tests}

All specimens showed the same failure mode, which consisted of a plane failure surface parallel to the shear stress. This failure plane coincided with the discontinuity defined by the two pieces of the shear box.

Figure 7 shows the maximum shear stress borne by each specimen and the corresponding normal stress. There is a specific graph for each tested combination of the production parameters: the particle size distribution of the soil mixture ("A" or "B" according to Figure 1), the compaction load $(2 \mathrm{kN}$ or $4 \mathrm{kN})$, the curing process and the addition or absence of bacteria. Additionally, these graphs show the linear fitting of the experimental points for each type of specimen. The slope of these linear regressions is a measurement of the corresponding apparent internal friction angle, $\phi$, and the point where every fitted line crosses the vertical axis is the corresponding apparent cohesion, $c$, determined in undrained confined testing conditions of partially saturated specimens. These two variables and the coefficient of determination, $R^{2}$, for each regression line are presented in the graphs.

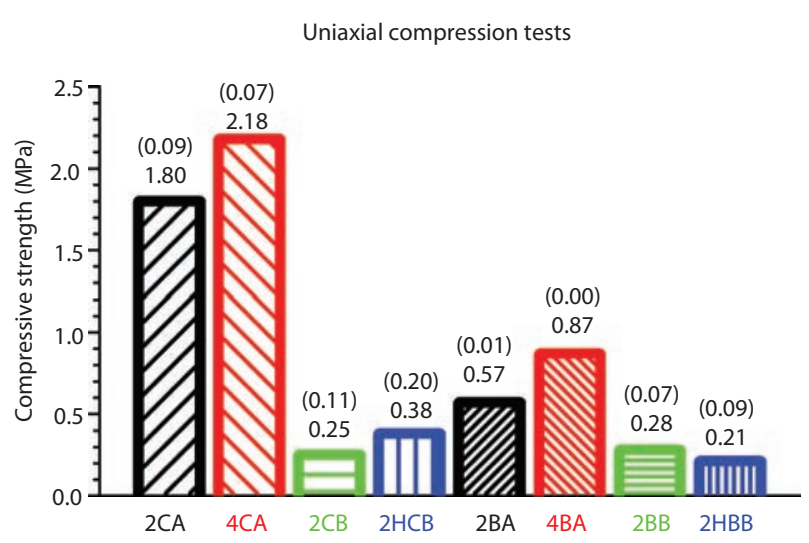

FIgURE 5. Results of the uniaxial compression tests.
Dilatancy was observed during the shearing process of some specimens (see Figure 8 and Table 4). It was identified by an upwards displacement of the vertical actuator during the application of the increasing shear force. This typical effect of granular materials was particularly observed for those specimens tested at the lowest normal stress.

\section{DISCUSSION}

The addition of Sporosarcina pasterurii modified compression stress, $f_{c}$, apparent cohesion, $c$, and apparent internal friction angle, $\phi$, for all specimens with mixture type "A". According to Figure 5 , Table 4 and Table 5, the value of these properties decreased in comparison with samples that did not contain bacteria. Moreover, dilatancy was also reduced with the addition of bacteria.

In contrast, adding Sporosarcina Pasteurii in the specimens produced with soil mixture "B" and cured under environmental conditions caused the increase in the compressive strength, $f_{c}$, and the apparent internal friction angle, $\phi$, while apparent cohesion, $c$, was reduced. Observation of dilatancy effects remained limited to direct shear tests at the lowest normal stress level.

Finally, the cases produced with soil mixture " $B$ " and cured under a high humidity environment showed a decrease in the compressive strength, $f_{c}$, and the apparent internal friction angle, $\phi$, whereas the apparent cohesion, $c$, increased and dilatancy effects and were more frequent when adding Sporosarcina Pasteurii.

Thus, the results indicate that bacterial activity modified the mechanical performance of the soil. There are two main variables which interact with the effect of adding bacteria: a) the size of the voids of the compacted specimens, which is related with the soil mixture and can be indirectly assessed through the value of the dry density of the specimens, shown in Table 2; and b) the availability of free water for the bacterial activity, which depends on the curing conditions.

TABLE 3. Compressive strength results. Coefficient of variation in brackets

\begin{tabular}{|c|c|c|c|c|c|}
\hline \multirow[b]{2}{*}{ Specimens } & \multicolumn{2}{|r|}{ Repetition 1} & \multicolumn{2}{|r|}{ Repetition 2} & \multirow[b]{2}{*}{ Average } \\
\hline & Sample & Compressive strength (MPa) & Sample & Compressive strength (MPa) & \\
\hline $2 \mathrm{CA}$ & 2CA1 & 1.69 & $2 \mathrm{CA} 2$ & 1.91 & $1.80(0.09)$ \\
\hline $4 \mathrm{CA}$ & 4CA1 & 2.29 & $4 \mathrm{CA} 2$ & 2.06 & $2.18(0.07)$ \\
\hline $2 \mathrm{CB}$ & $2 \mathrm{CB} 1$ & 0.21 & $2 \mathrm{CB} 2$ & 0.28 & $0.25(0.20)$ \\
\hline $2 \mathrm{HCB}$ & $2 \mathrm{HCB} 1$ & 0.41 & $2 \mathrm{HCB} 2$ & 0.35 & $0.38(0.11)$ \\
\hline 2BA & 2BA1 & 0.56 & 2BA2 & 0.57 & $0.57(0.01)$ \\
\hline 4BA & 4BA1 & 0.87 & 4BA2 & 0.86 & $0.87(0.00)$ \\
\hline $2 \mathrm{BB}$ & 2BB1 & 0.26 & $2 \mathrm{BB} 2$ & 0.29 & $0.28(0.07)$ \\
\hline $2 \mathrm{HBB}$ & 2HBB1 & 0.22 & 2HBB2 & 0.19 & $0.21(0.09)$ \\
\hline
\end{tabular}




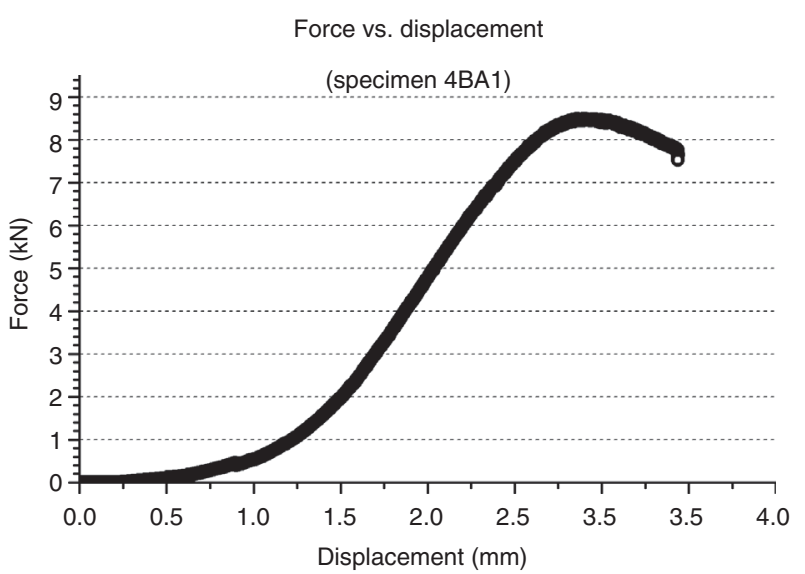

FIgURE 6. Force-displacement response for the uniaxial compression test of specimen 4BA1.

\subsection{Effect of particle size distribution}

According to the results, the particle size distribution influences the effectiveness of adding bacteria to cement compacted soil specimens. Thus, this parameter is analysed by comparing specimens $2 \mathrm{CA}, 2 \mathrm{CB}, 2 \mathrm{BA}$ and $2 \mathrm{BB}$.

The compressive strength, $f_{c}$, apparent cohesion, $c$, and apparent internal friction angle, $\phi$, were larger for the specimens produced with the soil mixture that contained more fine fraction, soil type "A", in comparison with specimens produced with mixture "B" (which was more similar to a sandy soil), as seen in Figure 5, Figure 7 and Table 5. This trend was more pronounced for the specimens without bacteria (2CA and $2 \mathrm{CB}$ ) than for the ones with added bacteria (2BA and $2 \mathrm{BB}$ ).

The dilatancy effect was observed for specimens 2CA tested under a normal stress of between 300 $\mathrm{kPa}$ to $900 \mathrm{kPa}$, whereas dilatancy was limited in the tests at $300 \mathrm{kPa}$ of normal stress for the specimens 2CB. In contrast, specimens with added bacteria and produced with both soil mixtures (2BA and 2BB) showed similar dilatancy effects, which were only observed under a normal stress of $300 \mathrm{kPa}$ during the direct shear test (see Figure 8 and Table 4).

Dilatancy shows the grain interlocking of the mixtures. Hence, for soil mixtures without bacteria, fine fraction decisively contributes to grain interlocking effect. Because soil mixture type "A" contains finer fraction, the grain interlocking effect is more relevant than for soil mixture type "B". This fact explains the higher values of compressive strength, apparent cohesion and apparent internal friction angle for the specimens produced with soil mixture "A".

In contrast, the addition of bacteria modifies the crucial role of the fine fraction. For specimens produced with mixture " $\mathrm{A}$ " and bacteria, the strength properties decrease. It is known that bacteria sporulate when they cease activity and leave small holes that weaken the more compact specimens. This effect has been reported by a previous research on mortar (see (7)) and may be supported by the fact that the amount of bacteria used is over the maximum proposed by other authors $($ see $(7,13))$. In this line, the larger pores of the specimens produced with soil mixture "B" caused the holes left by the sporulation of bacteria to be irrelevant. This hypothesis is also supported by the minor changes detected when adding bacteria into specimens produced with soil mixture "B".

Mechanical properties depended on the soil particle size for specimens without bacteria but the addition of bacteria seemed to reduce this influence. In the case of soil mixture type "A", bacteria reduced the grain interlocking and in the case of soil type "B", porosity was so large that bacteria did not substantially modify the grain interlocking.

\subsection{Effect of the curing process}

The effect of curing specimens in a high humidity environment is discussed by comparing $2 \mathrm{CB}$ vs $2 \mathrm{HCB}$ series for control cases and $2 \mathrm{BB}$ vs $2 \mathrm{HBB}$ series for cases with bacteria.

Compressive strength, $f_{c}$, and apparent internal friction angle, $\phi$, of the specimens without bacteria and cured at high humidity environment (2HCB) achieved higher values than for the comparable specimens cured under indoor environmental conditions (2CB). Nevertheless, the apparent cohesion, $c$, was lower for the specimens cured under a high humidity environment (2HCB). These results should be analysed while considering the significant difference in the moisture content between the two comparable series at the testing moment (see Table 2 ). The higher moisture content of the specimens $2 \mathrm{CB}$ would explain their response: the lower $f_{c}$ and $\phi$ values may be associated with lower matric suction, whereas the major deformability of the clay fraction may be associated with a higher apparent cohesion, $c$, in comparison with specimens $2 \mathrm{HCB}$.

The trend for the cases with added bacteria is the opposite: curing under a high humidity environment (2HBB) caused a slight increase of the apparent cohesion and the reduction of the compressive strength and the apparent internal friction angle in comparison with the specimens cured under environmental conditions (2BB). The moisture content of this series was equivalent, and thus the curing process influenced the bacterial activity. It is thought that the availability of water in the environment boosted the reproduction of bacteria and the corresponding biodeposition of $\mathrm{CaCO}_{3}$. The likely presence of more bacteria may have caused far more voids when the bacteria ceased activity and this fact may explain the reduction of the compressive strength of the samples cured under a high humidity 

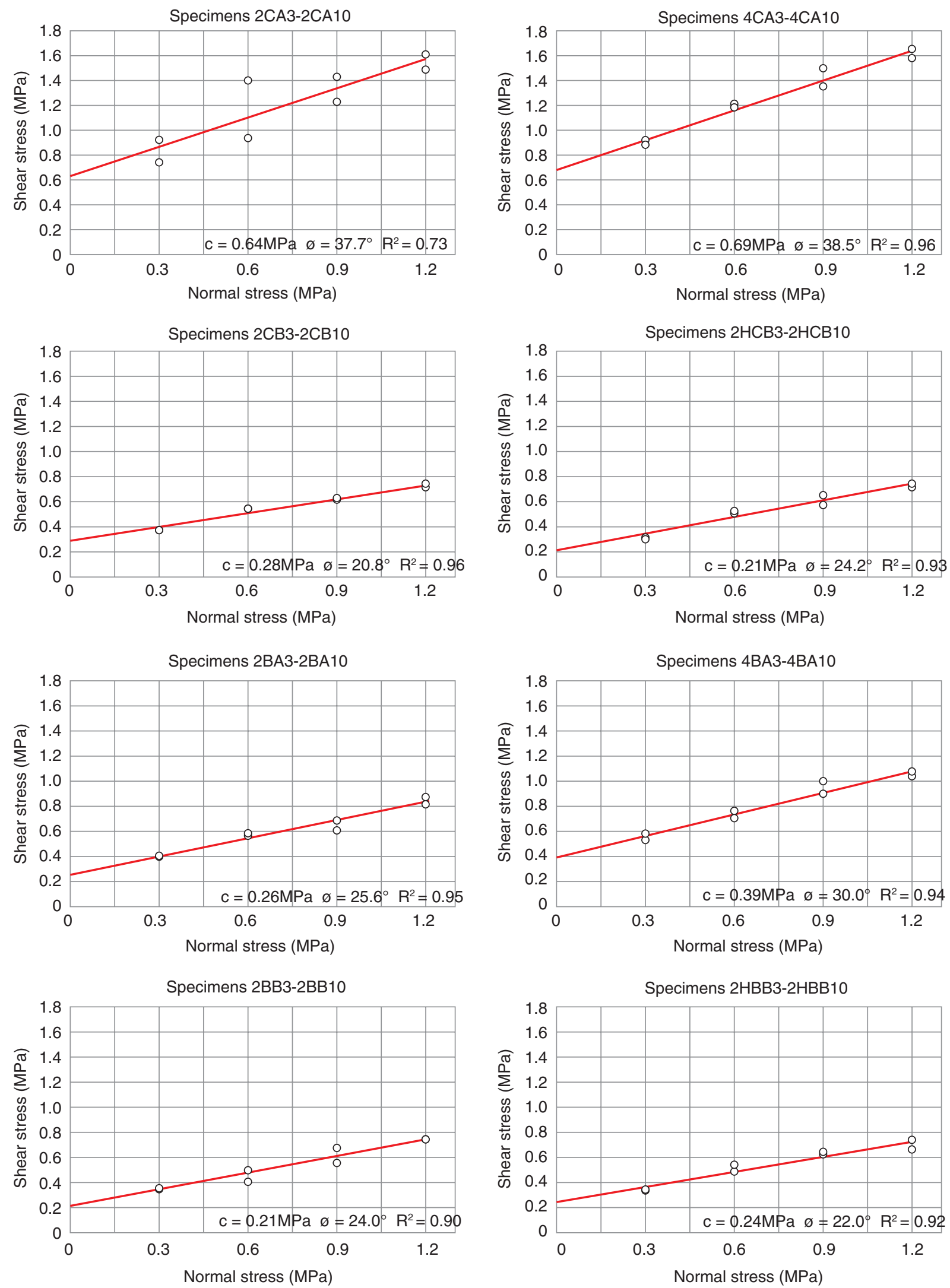

FIGURE 7. Mohr-Coulomb failure criteria obtained from the direct shear test results. Regression lines and apparent mechanical parameters for each specimen typology. 
Effect of Sporosarcina Pasteurii on the strength properties $\bullet 11$
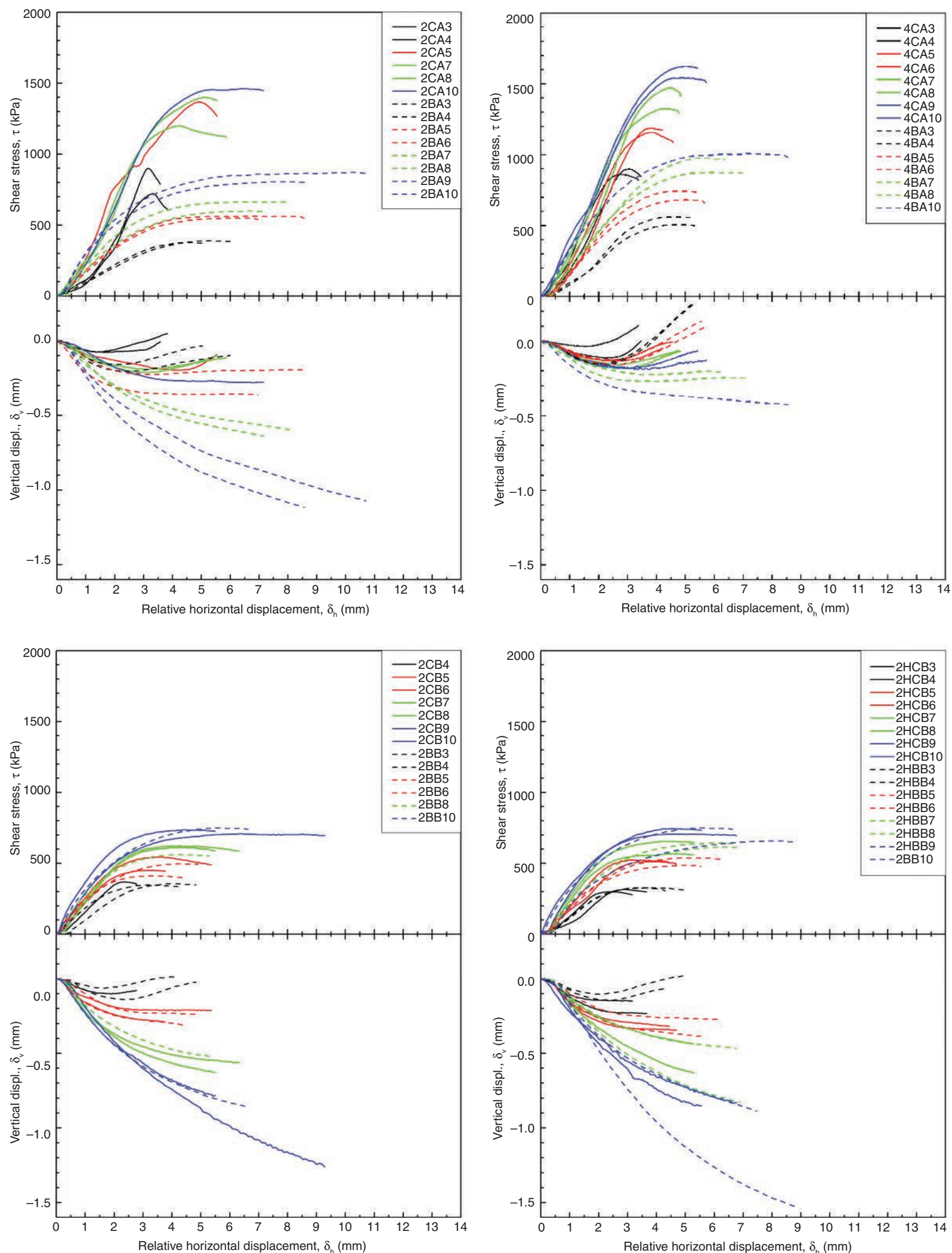

FIGURE 8. Mechanical response during the shearing process of the direct shear tests. Negative vertical displacement is descending movement. 
environment (2HBB) with respect to the specimens cured under indoor standard environmental conditions (2BB). The likely higher volume of $\mathrm{CaCO}_{3}$ generated would explain the cementation effect and the corresponding slight increase in the apparent cohesion, whereas the small decrease in the apparent internal friction angle may be explained by the separation of the granular particles due to the deposition of $\mathrm{CaCO}_{3}$. Finally, dilatancy effects were observed for specimens $2 \mathrm{HBB}$, which were not seen for the comparable specimens without bacteria (2HCB).

Thus, it seems that adding Sporosarcina Pasteurii only contributed to cement the grains of those samples which were cured into a high moisture environment. This implies that the bacterial activity requires free available water.

\subsection{Effect of compaction load}

Increasing the compaction load from $2 \mathrm{kN}$ to $4 \mathrm{kN}$ caused an increase of the strength properties (compressive strength, apparent cohesion and apparent internal friction angle) for all comparable cases (2CA vs $4 \mathrm{CA}$ and $2 \mathrm{BA}$ vs $4 \mathrm{BA}$ ), as seen in the results shown in Table 5. In addition, increasing the compaction load causes the generation of more dilatancy effects (see Table 4). These variations of strength properties and mechanical response are due to the greater density (see Table 2 ) and greater granular interlocking (see Table 4 and Figure 8) achieved by increasing the compaction load.

TABLE 4. Summary of the direct shear tests with dilatancy effects (shadowed)

\begin{tabular}{|c|c|c|c|c|}
\hline \multirow[b]{2}{*}{ Specimens } & \multicolumn{4}{|c|}{ Normal stress $(\mathrm{kPa})$} \\
\hline & 300 & 600 & 900 & 1200 \\
\hline $2 \mathrm{CA}$ & & & & \\
\hline $2 \mathrm{BA}$ & & & & \\
\hline $4 \mathrm{CA}$ & & & & \\
\hline 4BA & & & & \\
\hline $2 \mathrm{CB}$ & & & & \\
\hline $2 \mathrm{BB}$ & & & & \\
\hline $2 \mathrm{HCB}$ & & & & \\
\hline $2 \mathrm{HBB}$ & & & & \\
\hline
\end{tabular}

The decrease of the strength properties $\left(f_{c}, c\right.$ and $\phi$ ) due to the addition of bacteria is greater for the cases produced with a compaction load of $2 \mathrm{kN}$ than for the cases compacted at $4 \mathrm{kN}$, as seen in the results shown in the last three columns in Table 5. This tendency seems to indicate that bacterial activity is more likely in the specimens produced with a lower compaction load, which showed minor dry density (Table 2) and presented larger pores where bacteria can develop.

\section{CONCLUSIONS}

The primary conclusion is that microbial biodeposition of $\mathrm{CaCO}_{3}$ and bacterial activity can modify the mechanical properties of earthen construction materials. In addition, other specific conclusions can be drawn:

- Sporosarcina Pasteurii is presented in literature as the most suitable microorganism to induce the biological cementation of soils.

- The activity of Sporosarcina Pasteurii reduces the interlocking of granular particles in wellgraded soils.

- The activity of Sporosarcina Pasteurii increases the apparent cohesion of sandy soils cured under a high humidity environment.

- Sporosarcina Pasteurii requires free available water for its activity. Curing earth compressed cubes with bacteria in a high humidity environment contributes to the bacterial activity.

- Bacterial activity is more likely in specimens with large connected voids. Thus, an increase in the compaction load, which reduces the size of the voids, limits the bacterial production of $\mathrm{CaCO}_{3}$.

These conclusions demonstrate practical applications: (i) earthen construction is possible without clay if Sporosarcina Pasteurii is added and the produced elements are cured under a high humidity environment; (ii) microbial biodeposition of $\mathrm{CaCO}_{3}$ should be mainly induced in sandy non-compacted soils such as those found in river banks or beaches.

Further investigation would enhance the understanding of the following topics: a) the reduction

TABLE 5. Effect of adding Sporosarcina Pasteurii

\begin{tabular}{|c|c|c|c|c|c|c|c|c|c|c|}
\hline \multicolumn{4}{|c|}{ Without bacteria } & \multicolumn{4}{|c|}{ With bacteria } & \multicolumn{3}{|c|}{ Difference } \\
\hline Spec. & $\mathbf{f}_{\mathrm{c}}(\mathrm{MPa})$ & c (MPa) & $\phi\left(^{\circ}\right)$ & Spec. & $\mathbf{f}_{\mathrm{c}}(\mathrm{MPa})$ & c (MPa) & $\phi\left(^{\circ}\right)$ & $\Delta \mathbf{f}_{c}(\%)$ & $\Delta c(\%)$ & $\Delta \phi(\%)$ \\
\hline $2 \mathrm{CA}$ & 1.80 & 0.64 & 37.7 & $2 \mathrm{BA}$ & 0.57 & 0.26 & 25.6 & -68.3 & -59.4 & -32.1 \\
\hline $4 \mathrm{CA}$ & 2.18 & 0.69 & 38.5 & $4 \mathrm{BA}$ & 0.87 & 0.39 & 30.0 & -60.1 & -43.5 & -22.1 \\
\hline $2 \mathrm{CB}$ & 0.25 & 0.28 & 20.8 & $2 \mathrm{BB}$ & 0.28 & 0.21 & 24.0 & 12.0 & -25.0 & 15.4 \\
\hline $2 \mathrm{HCB}$ & 0.38 & 0.21 & 24.2 & $2 \mathrm{HBB}$ & 0.21 & 0.24 & 22.0 & -44.7 & 14.3 & -9.1 \\
\hline
\end{tabular}


of the binding effect of the surface tension of pore water in the clay fraction due to biodeposition of $\mathrm{CaCO}_{3}$; b) the effect of adding Sporosarcina Pasteurii on the pore distribution of compacted soil samples; and c) the reduction of granular interlocking due to biodeposition of $\mathrm{CaCO}_{3}$.

\section{ACKNOWLEDGEMENTS}

The authors want to acknowledge the support provided by Fabiola Meignen, Adrià López Puig and Elitsa Teneva during the experimental program and the support from the Department of Material Science and Metallurgic Engineering of the Polytechnic University of Catalonia, which provided access to their facilities and equipment.

This research has been carried out with the financial support of the grant 2014 PDJ 00105 from AGAUR, Generalitat de Catalunya, Spain.

\section{REFERENCES}

1. Easton, D., Wright, C. (2007). The Rammed Earth House. Vermont: Chelsea Green Publishing (2007)

2. Miccoli, L., Müller, U., Fontana, P. (2014). Mechanical behaviour of earthen materials: A comparison between earth block masonry, rammed earth and cob. Constr. Build. Mater, 61: 327-339, https://doi.org/10.1016/j. conbuildmat.2014.03.009

3. DeJong, J. T., Fritzges, M. B., Nüsslein, K. (2006). Microbially Induced Cementation to Control Sand Response to Undrained Shear. J. Geotech. Geoenvironmental Eng., 132(11): 1381-1392, https://doi.org/10.1061/ (ASCE)1090-0241(2006)132:11(1381)

4. Stocks-Fischer, S., Galinat, J. K., Bang, S. S. (1999). Microbiological precipitation of CaCO 3. Soil Biol. Biochem., 31(11): 1563-1571, https://doi.org/10.1016/ S0038-0717(99)00082-6

5. Ivanov, V., Chu, J., Stabnikov, V. (2015). Basics of Construction Microbial Biotechnology. In Biotechnologies and Biomimetics for Civil Engineering (pp. 21-56). Cham: Springer International Publishing (2015), https://doi. org/10.1007/978-3-319-09287-4_2

6. De Muynck, W., Debrouwer, D., De Belie, N., Verstraete, W. (2008). Bacterial carbonate precipitation improves the durability of cementitious materials. Cem. Concr. Res., 38(7): 1005-1014, https://doi.org/10.1016/j. cemconres.2008.03.005

7. Ramachandran, S. K., Ramakrishnan, V., Bang, S. S. (2001). Remediation of concrete using micro-organisms. ACI Mater. J., 98(1): 3-9.
8. Chunxiang, Q., Jianyun, W., Ruixing, W., Liang, C. (2009). Corrosion protection of cement-based building materials by surface deposition of $\mathrm{CaCO} 3$ by Bacillus Pasteurii. Mater. Sci. Eng. C, 29(4): 1273-1280, https://doi.org/10.1016/j. msec.2008.10.025

9. Jonkers, H. M., Thijssen, A., Muyzer, G., Copuroglu, O., Schlangen, E. (2010). Application of bacteria as selfhealing agent for the development of sustainable concrete. Ecol. Eng., 36(2): 230-235, https://doi.org/10.1016/j. ecoleng.2008.12.036

10. Sierra-Beltran, M. G., Jonkers, H. M., Schlangen, E. (2014). Characterization of sustainable bio-based mortar for concrete repair. Constr. Build. Mater, 67: 344-352, https://doi. org/10.1016/j.conbuildmat.2014.01.012

11. Bang, S. S., Galinat, J. K., Ramakrishnan, V. (2001). Calcite precipitation induced by polyurethane-immobilized Bacillus Pasteurii. Enzyme Microb. Technol., 28(4-5): 404 409, https://doi.org/10.1016/S0141-0229(00)00348-3

12. Bachmeier, K. L., Williams, A. E., Warmington, J. R., Bang, S. S. (2002). Urease activity in microbiologicallyinduced calcite precipitation. J. Biotechnol., 93(2): 171-181, https://doi.org/10.1016/S0168-1656(01)00393-5

13. Bang, S. S., Lippert, J. J., Yerra, U., Mulukutla, S., Ramakrishnan, V. (2010). Microbial calcite, a biobased smart nanomaterial in concrete remediation. Int. J. Smart Nano Mater, 1(1): 28-39, https://doi. org/10.1080/19475411003593451

14. Jonkers, H. M. (2011). Bacteria-based self-healing concrete. Heron, 56(1-2): 5-16

15. Wang, J. Y., Soens, H., Verstraete, W., De Belie, N. (2014). Self-healing concrete by use of microencapsulated bacterial spores. Cem. Concr. Res., 56: 139-152, https://doi. org/10.1016/j.cemconres.2013.11.009

16. Paassen, L. A. Van, Harkes, M. P., Zwieten, G. A. Van, Zon, W. H. Van Der, Star, W. R. L. Van Der, Loosdrecht, M. C. M. Van. (2009). Scale up of BioGrout : a biological ground reinforcement method Agrandissement de BioGrout: méthode biologique pour la consolidation des sols. 17th Int. Conf. Soil Mech. Geotech. Eng., 2328-2333, https://doi.org/10.3233/978-1-60750-031-5-2328

17. Bernat-Maso, E., Gil, L., Escrig, C. (2016). Textilereinforced rammed earth: Experimental characterisation of flexural strength and thoughness. Constr. Build. Mater., 106: 470-479, https://doi.org/10.1016/j. conbuildmat.2015.12.139

18. Committee D-18. (2004). D5102-04. Standard Test Method for Unconfined Compressive Strength of Compacted SoilLime Mixtures. Annu. B. ASTM Stand. Vol 04.08. West Conshohocken: ASTM International.

19. Committee D18 (2000) D6528-00. Standard Test Method for Consolidated Undrained Direct Simple Shear Testing of Cohesive Soils. West Conshohocken: ASTM International, https://doi.org/10.1520/D6528-07

20. Committee AEN/CTN 83 (2007) UNE-EN 101511:2000/A1:2007. Métodos de ensayo de los morteros para albañilería. Parte 11: Determinación de la resistencia a flexión y a compresión del mortero endurecido. Madrid: AENOR. 